\title{
SPOT Imagery and GIS in Support of Military Land Management
}

by

Steven D. Warren

Calvin F. Bagley

Due to the nature and intensity of the activities occurring on many military training areas, management of those lands can be a complex problem. The U.S. Army has adopted a standardized land condition and trend analysis approach to land management that incorporates the use of a geographic information system and satellite imagery. These tools are valuable for objective selection of field data collection sites, landcover classification, soil erosion prediction and estimation of military carrying capacity.

\section{For Reference}

Not to be taken from this room 
Public reporting burden for this coliection of information is estimated to average 1 hour per response, including the time for reviewing instructions, searching existing data sources, gathering and maintaining the data needed, and completing and reviewing the collection of information. Send comments regarding this burden estimate or any other aspect of this coliection of information, including suggestions for reducing this burden, to Washington Headquarters Services, Directorate for information Operations and Reports, 1215 Jefferson Davis Highway. Suite 1204. Arlington, VA 22202-4302, and to the Otfice of Management and Budget, Paperwork Reduction Project (0704-0188), Washington, DC 20503,

\begin{tabular}{|l|l|l|}
\hline 1. AGENCY USE ONLY (Leave Blank) & 2. REPORT DATE & 3. REPORT TYPE AND DATES COVERED
\end{tabular}

\begin{tabular}{l|l} 
4. TITLE AND SUBTITLE & 5. FUNDING NUMBERS
\end{tabular}

SPOT Imagery and GIS in Support of Military Land Management

6. AUTHOR(S)

Steven D. Warren and Calvin F. Bagley

PE 4A 16272

PR 896

WU NN-THO

U.S. Army Construction Engineering Research Laboratories (USACERL)

PO Box 9005

8. PERFORMING ORGANIZATION REPORT NUMBER

Champaign, IL 61826-9005

9. SPONSORING/MONITORING AGENCY NAME(S) AND ADDRESS(ES)

TM EN-93/02

U.S. Army Engineering and Housing Support Center (USAEHSC)

ATTN: CEHSC-FN

Bldg. 358

Fort Belvoir, VA 22060-5580

11. SUPPLEMENTARY NOTES

Copies are available from the National Technical Information Service, 5285 Port Royal Road,

Springfield, VA 22161.

12a. DISTRIBUTION/AVAILABILITY STATEMENT

12b. DISTRIBUTION CODE

Approved for public release; distribution is unlimited.

13. ABSTRACT (Maximum 200 words)

Due to the nature and intensity of the activities occurring on many military training areas, management of those lands can be a complex problem. The U.S. Army has adopted a standardized land condition and trend analysis approach to land management that incorporates the use of a geographic information system and satellite imagery. These tools are valuable for objective selection of field data collection sites, landcover classification, soil erosion prediction and estimation of military carrying capacity.

\begin{tabular}{|c|c|c|c|}
\hline \multirow{2}{*}{\multicolumn{3}{|c|}{$\begin{array}{l}\text { 14. SUBNECT TERMS } \\
\text { training lands } \\
\text { Land Condition Trend Analysis (LCTA) } \\
\text { geographic information systems (GIS) }\end{array}$}} & $\begin{array}{c}\text { 15. NUMBER OF PAGES } \\
16\end{array}$ \\
\hline & & & 16. PRICE CODE \\
\hline $\begin{array}{l}\text { 17. SECURITY CLASSIFICATION } \\
\text { OF REPORT } \\
\text { Unclassified }\end{array}$ & $\begin{array}{l}\text { 18. SECURITY CLASSIFICATION } \\
\text { OF THIS PAGE } \\
\text { Unclassified }\end{array}$ & $\begin{array}{l}\text { 19. SECURITY CLASSIFICATION } \\
\text { OF ABSTRACT } \\
\text { Unclassified }\end{array}$ & $\begin{array}{l}\text { 20. LIMITATION OF ABSTRACT } \\
\text { SAR }\end{array}$ \\
\hline
\end{tabular}

NSN 7540-01-280-5500

Sandard Form 296 (Rev $2 \%$ ) Prescribed by ANSI Sid 23918 298-102 


\section{FOREWORD}

This article was published in Geocarto International 7 (1) 1992, pp 35-44, published by Geocarto International Centre, G.P.O. Box 4122, Hong Kong, and is reprinted with permission. The work was funded by the U.S. Army Engineering and Housing Support Center (USAEHSC) under project 4A162720896, "Base Facility Environmental Quality"; Work Units NN-TH0, "Advanced Methods for Evaluating/Monitoring Training Land Soil Resources" and NN-TS1, "Imagery Data for Training Area Management." The USAEHSC technical monitor is Dr. Victor E. Diersing, CEHSC-FN.

The research was performed by the Environmental Natural Resources Division (EN) of the Environmental Sustainment Laboratory (EL), U.S. Army Construction Engineering Research Laboratories (USACERL). Dr. William Severinghaus is Acting Chief, CECER-EN. William Goran is Acting Chief, CECER-EL.

COL Daniel Waldo, Jr., is Commander and Director of USACERL, and Dr. L.R. Shaffer is Technical Director. 


\title{
SPOT Imagery and GIS in Support of Military Land Management
}

\author{
Steven D. Warren and Calvin F. Bagley \\ US Army Construction Engineering Research Laboratory \\ Environmental Division \\ PO Box 9005 \\ Champaign, IL 61826-9005
}

\begin{abstract}
Due to the nature and intensity of the activities occurring on many military training areas, management of those lands can be a complex problem. The US Army has adopted a standardized land condition and trend analysis approach to land management that incorporates the use of a geographic information system and satellite imagery. These tools are valuable for objective selection of field data collection sites, landcover classification, soil erosion prediction and estimation of military carrying capacity.
\end{abstract}

\section{Introduction}

As technological advances have improved the firepower, maneuverability and mobility of modern weaponry, the size of anticipated future battlefields has increased dramatically (Department of the Army 1978). The evolution of military training tactics to simulate changing combat scenarios has led to increased demands on a limited military training land resource base. Military lands often serve a variety of additional uses as well, including timber production, agriculture, livestock grazing, off-road vehicle recreation and hunting. In light of the potential cumulative effects of larger-scale and more intense military training, coupled with other uses, the military community has become increasingly aware of the need to maintain or improve the condition of its training lands. The US Army, which manages approximately 12.5 million acres, has adopted a comprehensive training area management program designed to integrate natural resource concerns with military training needs (Diersing 1990). The keystone of integrated training area management is the standardized Land Condition-Trend Analysis (LCTA) program for collecting, analyzing and reporting information regarding kinds, amounts and conditions of existing resources (Wolff 1990).

Most land resource characteristics can be thought of in a geographic context, thus lending themselves to manipulation by computerized geographic information systems (GIS). In addition, satellite imagery has shown significant promise in a variety of land management applications. In this document we describe how GIS and satellite imagery are used with the LCTA program to provide a basis and a tool for improved land management decisions. These applications include the selection of field data collection sites, landcover classification, soil erosion prediction and estimation of military carrying capacity.

The geographic information system used was the Geographical Resources Analysis Support System (GRASS), a public domain system developed by the US Army Construction Engineering Research Laboratory (Westervelt 1988). GRASS includes functions to read, geometrically rectify, filter and classify remote imagery, and to integrate images with other geographic data. All cartographic data used in this document were resampled to $20 \mathrm{~m}$ grid-cell (raster) format prior to any analyses, thereby corresponding to the resolution of the satellite imagery. Satellite images were acquired by the French SPOT (Systeme Probatoire pour l'Observation de la Terre) satellite. SPOT measures relative spectral reflectance in the green $(0.50$ to $0.59 \mu \mathrm{m})$, red $(0.61$ to $0.68 \mu \mathrm{m})$ and near infrared $(0.79$ to $0.89 \mu \mathrm{m})$ portions of the electromagnetic spectrum.

\section{Site Selection}

Under the LCTA program, field data for any given military installation are collected from permanently established plots (Tazik et al. 1991). These plots are monitored annually in order to determine trends in resource condition over time. Information is recorded with regard to plant cover, plant canopy structure, plant species composition, and evidence of physical 
disturbance. Manpower, time and monetary constraints limit the number of plots that can be established and monitored. Therefore, it is imperative that the plots are as representative as possible of the kinds and conditions of land resources that exist on the installation.

In order to ensure objectivity and representativeness in the placement of the plots, a procedure was developed to automate the site selection process (Warren et al. 1990). The procedure incorporates digital soil surveys, SPOT imagery and GRASS. The first step in the site selection process is the acquisition of satellite imagery taken during the peak of the growing season. Using GRASS, an unsupervised classification is performed on the image, allowing the selection of up to 20 spectral categories based on reflectance values in the available spectral bands.

Because landcover types (and their associated spectral categories) are not randomly distributed in nature, a simple random allocation of a limited number of sample sites may not adequately represent all spectrally recognized landcover categories. Stratification of sampling sites by spectral categories ensures that all categories are better represented. However, due to the nature of remotely sensed spectral data, considerable variation in plant cover and botanical composition often exists within spectral categories. Differences in these variables are often related to the underlying soils. Therefore, a digital soil survey is incorporated as a secondary stratifier.

Within GRASS, the spectral category data layer derived from the unsupervised classification is superimposed on a digital soil survey of the area. Each unique spectral category/soil combination is recognized as a separate category. Each individual occurrence of the various combinations is identified as a separate polygon. Polygons less than 2 hectares ( 5 acres) in size are removed from the sample pool due to the difficulty in locating and sampling them in the field.

A user-determined number of field sample sites are allocated to the remaining polygons through a stratified random process. The number of sites assigned to an individual spectral category/soil combination is proportional to the percent of the land area that it covers. These sites are randomly assigned to the array of all polygons which comprise that combination. This process removes subjectivity from the site selection process while ensuring that all landcover types are represented in the sampling strategy. The use of the digital soil survey as a secondary stratifier provides a basis for postclassification sorting where ground data reveal significant variability in landcover within the spectral categories.
Field crews are provided with plastic overlays registered to U.S. Geologic Survey $7.5 \mathrm{minu}$ quadrangle maps. The overlays are color-printea with all eligible polygons; symbols identify the locations of the sample sites (e.g., Figure 1). With these maps and a list of the Universal Transverse Mercator coordinates of each site, field crews establish the permanent plots at the locations identified on the overlays. Global positioning systems are used to establish exact locations in areas where landmarks are scarce.

\section{Landcover Classification}

The standard US Army land condition and trend analysis plot is $100 \mathrm{~m}$ by $6 \mathrm{~m}$, with a $100 \mathrm{~m}$ line transect forming the central, longitudinal axis (Tazik et al. 1991). A modified point intercept method is used to document ground cover, surface disturbance, species composition, and vertical distribution of the plant canopy along the line transect. The density and size distribution of woody species is characterized by noting the location, size and species of all trees and shrubs within the $600 \mathrm{~m}^{2}$ plot. The data is processed by an algorithm that classifies each plot according to systems modified from those developed by the United Nations Education, Scientific and Cultur Organization (1973) and the US Forest Service (Driscolyet al. 1984). Each plot is classified as a woodland, shrubland, grassland or forbland. Woodland and shrubland communities are classified as coniferous or broadleaf; grassland and forbland communities are classified as perennial or annual. All major classes may be further subdivided as dense, closed, open or sparse communities (76-100, 51-75, 26-50 and 10-25\% aerial cover, respectively). Areas with less than $10 \%$ vegetative cover are classified as barren.

The spectral categories resulting from the unsupervised classification of the SPOT image are assigned the plant community class occurring most often on the plots representing them. Where significant variation occurs within one of the spectral categories, it may be subdivided based on differences in the underlying soils as provided for by the site allocation strategy. Accuracy of the resulting landcover map can be assessed based on the percent agreement of plot data with imagery categories. Figure 2 is a landcover map created for Hohenfels Combat Maneuver Training Center, Germany. Classification accuracy of the map is $76 \%$.

\section{Soil Erosion Estimation}

To satisfy the need for a quantitative assessment of soil stability on Army lands, a land capability 
classification system has been devised through the integration of the Universal Soil Loss Equation (USLE), GRASS, SPOT imagery and ground data from the land condition and trend plots (Warren et al. 1989). The USLE has the form

$\mathrm{A}=\mathrm{R} \times \mathrm{K} \times \mathrm{LS} \times \mathrm{C} \times \mathrm{P}$,

where the estimate of current average annual sheet and rill erosion (A) is determined from factors representing climate (R), soil erodibility (K), topography (LS), cover (C) and conservation support practices (P). Although not a part of the USLE per se, a soil loss tolerance factor (T) is commonly used in conjunction with the equation.

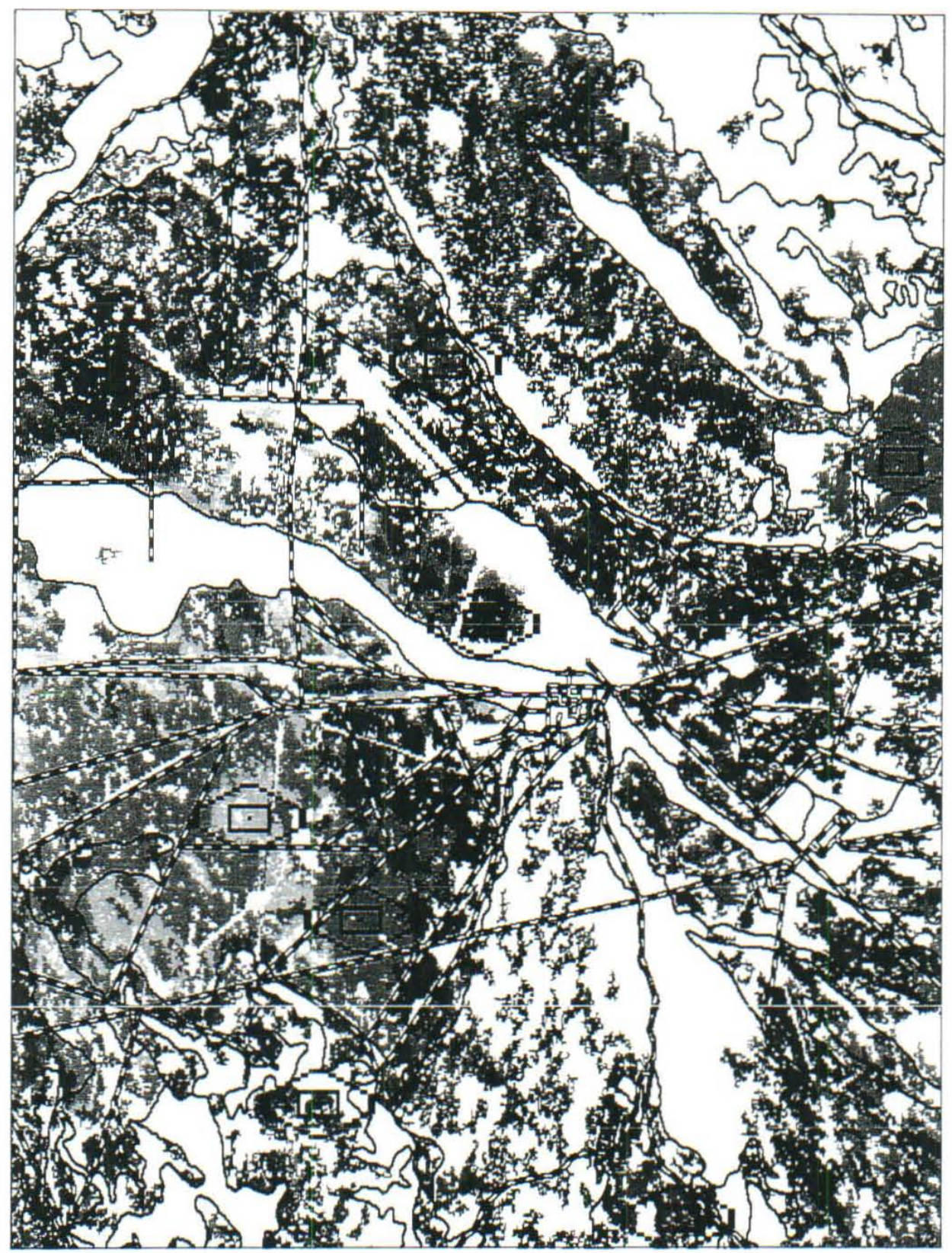

Figure 1 An example of a site allocation overlay map for the Camels Back Ridge NW quadrangle map at Dugway Proving Ground, Utah. The color scheme for the polygons represents the various undefined spectral categories derived from an unsupervised classification of a SPOT image. Soil series delineations are outlined in black. Symbols identify locations selected for inventory. Uncolored areas were dropped from the sampling scenario due to the disproportionately small contribution of spectral category/soil combinations to the installation as a whole, or due to the small size of the individual polygons (i.e., $<2 \mathrm{ha}$ ). 


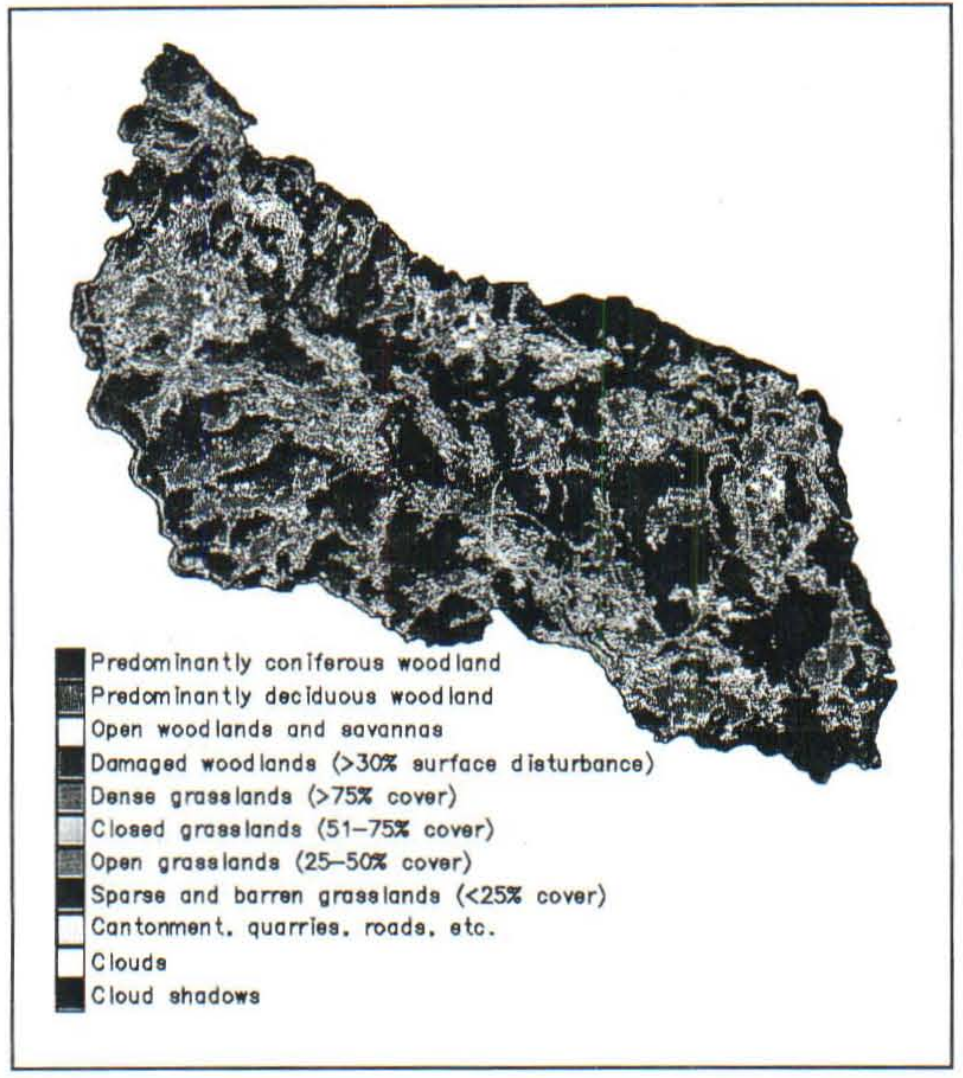

Figure 2 A landcover map of Hohenfels Combat Maneuver Training Center, Germany produced by using US Army land condition and trend analysis data to define spectral categories from an unsupervised classification of a 1987 SPOT satelli' image.

Figure 3 Soil erosion status map of Fort Riley, Kansas for 1988. Erosion status is the ratio of estimated soil loss to the level of soil loss tolerance. Values less than $100 \%$ indicate that soil erosion estimates fall within an acceptable range. As values increase beyond $100 \%$, the soil erosion status is increasingly unacceptable. White areas represent water.

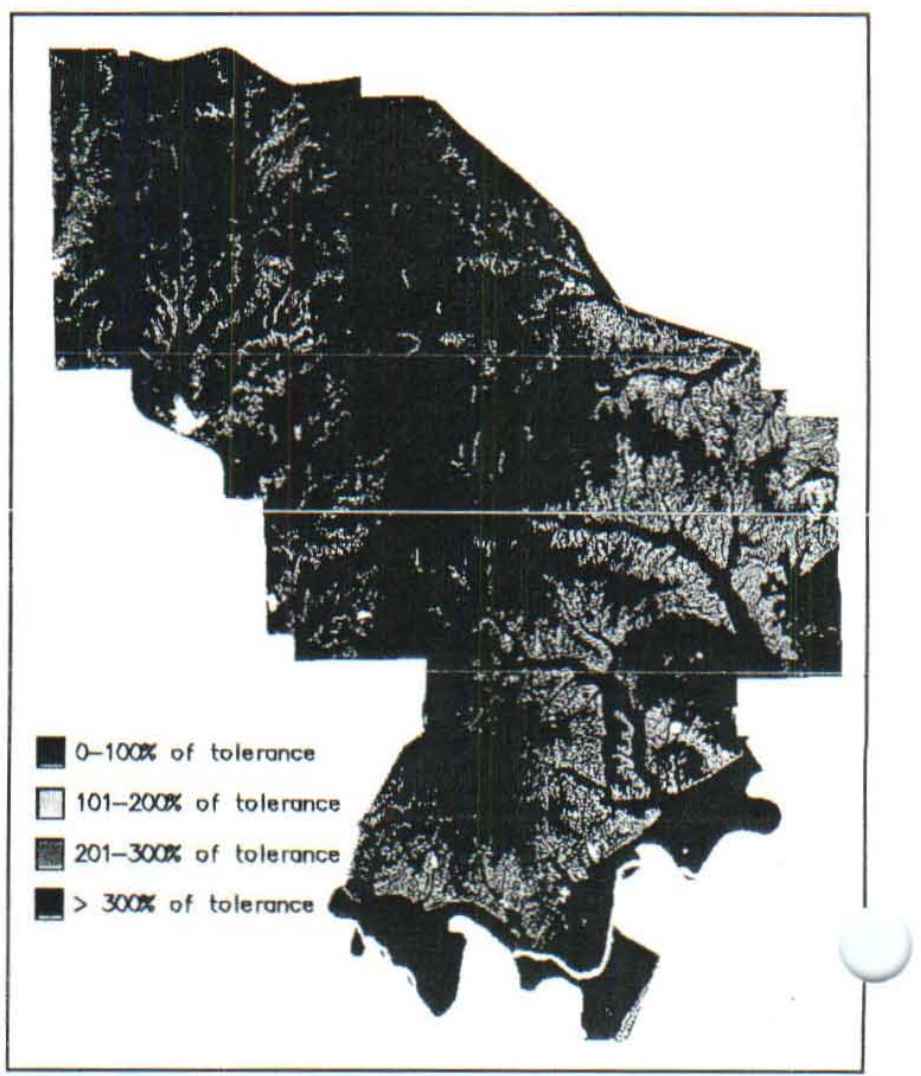




\subsection{Factor Estimation}

\subsubsection{R Factor.}

The $\mathrm{R}$ factor is a quantitative expression of the erosivity of local average annual precipitation and runoff. It can be obtained from governmental land management agencies or from isoerodent maps published in a variety of sources (e.g., Wischmeier and Smith 1978), or it can be calculated (Wischmeier 1959, Onchev 1985) or estimated (Arnoldus 1980) from local precipitation data. Because the $\mathrm{R}$ factor is generally constant over an area the size of a military installation, there is seldom a need to create a special map layer for this factor within GRASS.

\subsubsection{K Factor.}

This factor reflects the natural erodibility of soils. It is dependent on soil texture, organic matter content, structure, and permeability. The $\mathrm{K}$ factors for many soil series are published in local or regional soil surveys. They may also be determined by comparing analyses of soil samples collected in the field with a soil erodibility nomograph (Wischmeier and Smith 1978). Whatever the source, a K factor map layer is created by reclassing a soil series map layer with the respective $\mathrm{K}$ factor values.

\subsubsection{LS Factor.}

The rate of soil erosion by water is significantly affected by both the length and steepness of land slopes. The LS factor provides a quantitative representation of these topographic effects. Slope length and gradient are determined in the field in conjunction with the land condition and trend plots. These values are entered into a slope effect chart (Renard 1987), and LS factors are derived. A mean LS factor is calculated for each soil series, and the soil series map layer is reclassed using the respective LS factors, thus creating an LS factor map layer.

\subsubsection{Factor.}

This factor reflects the degree of erosion protection afforded by various soil covers. It is dependent on the height and extent of vegetative canopy, and the kind and amount of cover in contact with the soil (Wischmeier and Smith 1978). All pertinent information for computing $\mathrm{C}$ factors is collected on the land condition and trend analysis plots. To create a $\mathrm{C}$ factor map layer, each spectral category from the unsupervised classification of the SPOT image is reclassed according to the average $C$ value of the plots that represent it

\subsubsection{P Factor.}

The $\mathrm{P}$ factor is a quantitative expression of the mitigating effect that conservation support practices (e.g., contour tillage, strip cropping, terraces, etc.) have on the erosion process. Such conservation practices, however, are generally incompatible with the military training mission. Therefore, $\mathrm{P}$ is assigned a constant value of 1 , such that it has no effect on the erosion estimate provided by the USLE.

\subsubsection{T Factor.}

The $\mathrm{T}$ factor is an expression of soil loss tolerance, or the amount of soil that can be eroded on an annual basis without causing permanent damage to the land. $\mathrm{T}$ factors are often published in soil surveys, but may also be obtained from government land management offices, or may be estimated based upon the rooting depth of the soil (McCormack et al. 1982). A T factor map layer is created in GRASS by reclassing a soil series map layer according to appropriate $\mathrm{T}$ factor values.

\subsection{Products}

\subsubsection{Erosion Status.}

By solving the USLE with map layers for the various component factors, it is possible to produce a map illustrating the estimated erosion rate (A) for each 20 $\mathrm{m}$ by $20 \mathrm{~m}$ parcel of land at a military installation. By itself, however, the annual soil loss estimate is of little practical value. The erosion status or ratio of estimated soil loss (A) to soil loss tolerance (T) is a more accurate basis from which to evaluate the condition of the land, hence the equation

Erosion status $=\mathrm{A} / \mathrm{T}=(\mathrm{R} \times \mathrm{K} \times \mathrm{LS} \times \mathrm{C} \times \mathrm{P}) / \mathrm{T}$.

The solution to this equation is produced by performing the mathematical operations on a cell-bycell basis within GRASS. Areas with erosion status values less than $100 \%$ are predicted to be in acceptable condition for military use; as erosion status values increase beyond $100 \%$, they represent areas of increasingly unsatisfactory condition. Figure 3 illustrates an example of a soil erosion status map for Fort Riley, Kansas.

\subsubsection{Erodibility Index.}

Another variable of interest to the military land manager is the inherent erosion potential of the land. By substituting $\mathrm{T}$ for $\mathrm{A}$ in the USLE, and solving for the reciprocal of $\mathrm{C}$, the equation becomes

Erodibility Index $=1 / \mathrm{C}=(\mathrm{R} \times \mathrm{K} \times \mathrm{LS} \times \mathrm{P}) / \mathrm{T}$.

The product is an index of potential erosion. For agricultural purposes, areas with erodibility indices greater than 8 are considered highly erodible (Benbrook 1988). However, on lands that are not tilled or fallowed, the $\mathrm{C}$ factor rarely exceeds half the maximum value for cropped lands (Wischmeier 1975). Therefore, for military purposes, lands are not considered highly erodible until the erodibility index exceeds at least 16. A soil erodibility index map for Fort Riley is shown in Figure 4.

\subsection{Applications}

A land classification system based on soil erosion has a broad range of applications for military trainers 
and land managers. They include:

\subsubsection{Soil stability inventories.}

Color-coded maps can be provided that graphically illustrate the current erosion status (Figure 3), erodibility index (Figure 4), or any of the component data layers, thus providing a visual display of land characteristics or conditions. In addition, GRASS produces a numerical or tabular accounting of the extent of various categories within a given data layer. Comparisons of maps or reports of the erosion status from year to year can reveal trends of improving or declining condition.

\subsubsection{Training schedules.}

Based on the spatial distribution of erosion status and erodibility index categories, intensive military training activities can be scheduled to avoid severely degraded and highly sensitive areas. In addition, a mean erosion status or erodibility index can be calculated for individual training areas at a military installation to facilitate scheduling based on the ability of those areas to support military maneuvers.

\subsubsection{Training area demarcation.}

The erodibility index map can be used to demarcate individual training areas at military installations such that the land included within each area is relatively uniform in terms of its inherent capacity to withstand training pressure. This can greatly simplify the management and scheduling.

\subsubsection{Land rehabilitation.}

The erosion status map is useful in identifying areas that are potentially overused or badly degraded and that are in need of rest or some form of land rehabilitation. These areas should be removed from training schedules until their condition has improved to the point where they can again support training activity without exceeding tolerable levels of soil loss.

\subsubsection{Land acquisition.}

Both erosion status and erodibility index maps can provide valuable criteria for evaluating sites proposed for acquisition. Lands identified as badly degraded or highly erodible should not be considered for purchase or lease as military training lands.

\section{Carrying Capacity Estimate}

Carrying capacity is a term often used in the field of range management to describe the amount of standing forage that can be removed by grazing animals without causing long-term damage to the vegetation and related resources (Holechek 1989). Due to the nature and extent of the damage caused by offroad vehicular traffic, albeit much less selective than that caused by grazing animals, military vehicles can also be considered consumers of vegetation. In that context, the concept of carrying capacity is applicable to military training. However, while livestock owner are concerned with maintaining a forage base nutritious plants, military land managers are less concerned with botanical composition and more concerned with maintaining sufficient biomass and vegetative cover to prevent excessive soil erosion.

\subsection{Estimation Procedure}

Diersing et al. (1988) have developed a guide for estimating the military carrying capacity of lands. The estimates are based on predicting the amount of military traffic that a land area can withstand without exceeding estimated soil loss tolerance.

\subsubsection{Soil erosion estimates.}

The first step estimates average annual soil erosion on tracked $\left(\mathrm{A}_{\mathrm{t}}\right)$ and untracked $\left(\mathrm{A}_{\mathrm{u}}\right)$ portions of the land areas represented by each spectral category derived from the unsupervised classification of the SPOT image. During the collection of the land condition and trend field data, a determination of the presence or absence of tactical vehicle disturbance is made at each point along the point-intercept line transect, thus facilitating a determination of a cover factor $\left(C_{t}\right.$ or $\left.C_{u}\right)$ for tracked and untracked portions, respectively. The USLE is solved separately for tracked and untracked portions of the spectral categories and a separate data layer is created $f$ each.

\subsubsection{Maximum one-time surface use.}

In the second step, a GRASS map layer representing the maximum allowable one-time surface disturbance $\left(D_{1}\right)$ is created on a grid-cell by grid-cell basis using the equation

$$
\mathrm{D}_{1}=\left(\mathrm{T}-\mathrm{A}_{\mathrm{u}}\right) /\left(\mathrm{A}_{\mathrm{t}}-\mathrm{A}_{\mathrm{u}}\right) \times 100 .
$$

This data layer is an expression of the percent of the soil surface that could be disturbed on a one-time basis without causing excessive vegetation loss and, consequently, soil erosion in excess of soil loss tolerance.

\subsubsection{Maximum annual surface use.}

If, during a single year, training maneuver damage were to reach the maximum allowable one-time surface disturbance, future maneuvers would need to be postponed until the area had recovered. Depending on the location, the recovery period could require several years. To determine the allowable use on a sustained (annual) basis rather than on a one-time basis, it is necessary to create a data layer that contains, for each soil series, an estimate of the time (years) required to regrow an equivalent amount of soilprotecting cover following a single pass of a tactical vehicle. The maximum one-time surface use $\left(D_{1}\right) \mathrm{me}$ layer is divided by the estimated recovery rate ( $\mathrm{R}_{c}$ map layer to approximate the percent annual allowable surface disturbance $\left(D_{A}\right)$. 


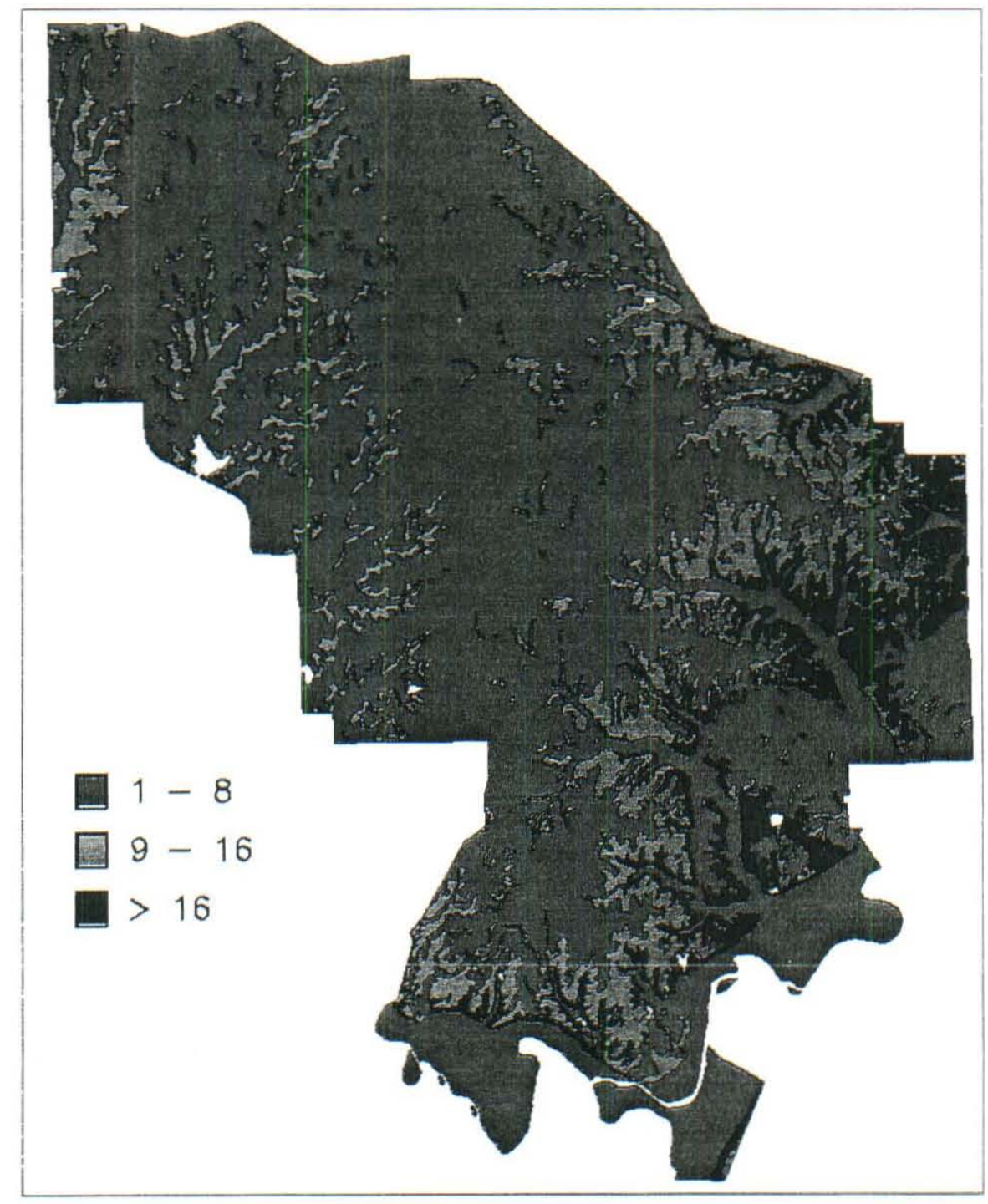

Figure 4 Erodibility index map of Fort Riley, Kansas. Erodibility indices greater than 16 are considered highly erodible. White areas represent water.

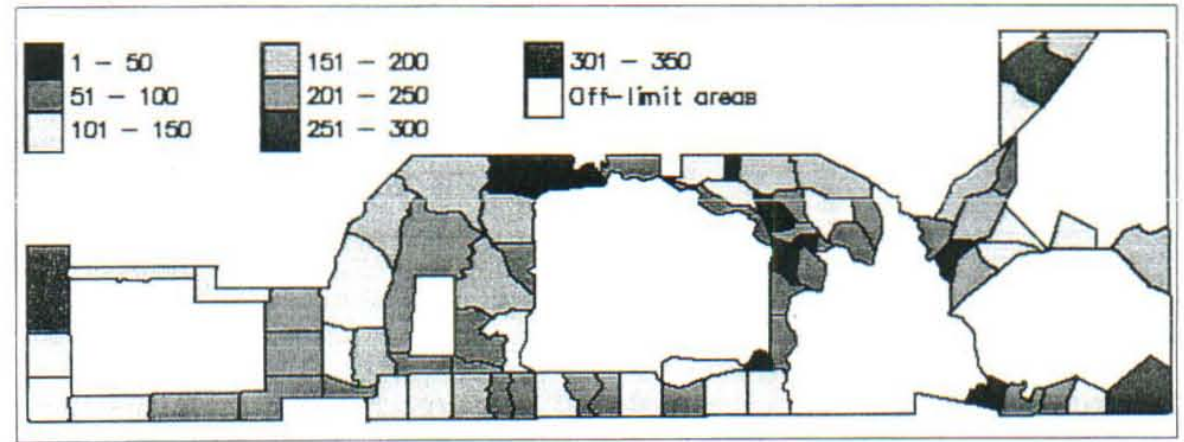

Figure 51988 carrying capacity map for Fort Sill, Oklahoma expressed in tactical vehicle days (TVDs). A tactical vehicle day at Fort Sill is a measure of surface disturbance caused by the passage of an M60 tank over an off-road distance of 6 miles. 


\subsubsection{Usable acres.}

Most US Army training installations are subdivided into numerous training areas. The next step in the calculation of carrying capacity requires a conversion of annual allowable surface disturbance from a percent to an acreage value for each training area. To determine the usable acreage of a given area, it is first necessary to exclude portions that are considered unusable for reasons other than estimated excessive soil erosion. These may include highly erodible portions, endangered species habitat, riparian buffer zones, artillery impact zones, etc. Following exclusion of the unusable portions, the average $D_{A}$ value for the remainder of the area is multiplied by the remaining acreage of the area to produce a data layer reflecting usable acres per year.

5.1.5 Tactical vehicle days.

The final step is to calculate allowable tactical vehicle days (TVDs) per year. The standard TVD is defined by the off-road area disturbed by an M60 tank during a typical day of training. With a combined track width of 4.67 feet (Foss 1987) and an estimated daily off-road travel distance of 6 miles, this value is 3.42 acres. All other military vehicles can be converted to TVD equivalents (Table 1 ). The total usable acreage of an area is divided by 3.42 to provide the total allowable TVDs per year. Figure 5 provides an example of carrying capacity for Fort Sill, Oklahoma.

\subsection{Applications}

For the purpose of scheduling training exercise the number of vehicles of each type that will be involved in the exercise must be determined. These numbers are multiplied by their respective TVD equivalents and by the number of days that they will be active during the maneuver. Table 2 provides a hypothetical calculation for Fort Sill, Oklahoma. The total TVDs for the exercise can be compared to the carrying capacity of the various training areas in order to select an area of sufficient capacity. After the exercise, the total expended TVDs should be subtracted from the annual carrying capacity estimate. Once usage levels reach carrying capacity for a given area, further training in that area should be suspended until the next year.

\section{Conclusions}

The US Army faces the unique challenge of maintaining and improving the condition of lands that are subjected to frequent, intense military training activities as well as additional nonmilitary uses. Proper management is dependent, at least in part, on accurate assessment of the present condition and future capacity of the land to support such activities. A standardized land condition and trend analys: program has been developed to provide such an

Table 1 Tactical vehicle day (TVD) equious military vehicles used at Fort Sill, Oklahoma.

\begin{tabular}{cccccc}
\hline Vehicle & $\begin{array}{c}\text { Combined Track/Tire } \\
\text { Width (ft) }\end{array}$ & $\begin{array}{c}\text { Acres Disturbed } \\
\text { Per mile }\end{array}$ & $\begin{array}{c}\text { Off-Road } \\
\text { Mileage Per Day }\end{array}$ & $\begin{array}{c}\text { Acres Disturbed } \\
\text { Per Day }\end{array}$ & Tvd Equivalent \\
\hline $\begin{array}{c}\text { M60 tank } \\
\text { M110 A2 Self-Propelled } \\
\text { Howitzer }\end{array}$ & 4.67 & 0.57 & 6.0 & 3.42 & 1.00 \\
$\begin{array}{c}\text { Multiple Launch Rocket } \\
\text { System }\end{array}$ & 3.00 & 0.36 & 1.0 & 0.36 & 0.11 \\
$\begin{array}{c}\text { M113 Armored Personnel } \\
\text { Carrier }\end{array}$ & 3.50 & 0.42 & 15.0 & 6.30 & 1.84 \\
\hline
\end{tabular}

Table 2 Hypothetical calculation tacitical vehicle days (TVDs) for a twelve-day training exercise at Fort Sill Oklahoma. TVDs are calculated by multiplying the number of each type by the number of days that they will be active and their respective TVD equivalents.

\begin{tabular}{ccccc}
\hline Vehicle Type & Number & Days & TVD Equivalent & TVDs \\
\hline M110 A2 Self-Propelled Howitzer & 5 & 12 & 0.11 & 6.6 \\
Multiple Launch Rocket System & 6 & 12 & 1084 & 132.6 \\
M113 Armored Personnel Carrier & 5 & 12 & 0.09 & 504 \\
\hline
\end{tabular}


assessment. Integration of field data with satellite imagery and a soil erosion model in a geographic information system environment significantly enhances the scope and utility of the program.

\section{Acknowledgements}

This work was funded by the US Army Corps of Engineers, Engineering and Housing Support Center. Paul C. Dubois and Keith D. Harris directed the collection of field data at Fort Riley, Kansas, and Fort Sill, Oklahoma, respectively. David G. Kowalski and William L. Sprouse were responsible for data analysis. Cynthia A. Abrahamson assisted with the creation of the GRASS graphics. David J. Tazik is the LCTA project coordinator.

\section{References}

Arnoldus, H.M.J. 1980. An Approximation of the Rainfall Factor in the Universal Soil Loss Equation, pp.127-132 in M. De Boodt and D. Gabriels (editors), Assessment of Erosion. John Wiley \& Sons, Chichester, England.

Benbrook, C.M. 1988. First Principles: The Definition of Highly Erodible Land and Tolerable Soil Loss. Journal of Soil and Water Conservation 43:35-38.

Diersing, V.E. 1990. ITAM Can Help Achieve Army Leaders' Environmental Goals. Integrated Training Area Management Technology Transfer Bulletin 91-1(1):1,2. US Army Construction Engineering Research Laboratory, Champaign, Illinois.

Diersing, V.E., R.B. Shaw, S.D. Warren and E.W. Novak. 1988. A User's Guide for Estimating Allowable Use of Tracked Vehicles on Nonwooded Military Training Lands. Journal of Soil and Water Conservation 43:191-195.

Driscoll, R.S., D.L. Merkel, D.L. Radloff, D.E. Snyder and J.S. Hagihara.1984. An Ecological Land Classification Framework for the United States. US Department of Agriculture, Forest Service Miscellaneous Publication 1439. 56pp.

Foss, C.F. (Editor). 1987. Jane's Armor and Artillery. Jane's Publishing Company Limited, London.1062pp.

Holechek, J.L., R.D. Pieper and C.H. Herbel. 1989. Range Management. Prentiss-Hall, Inc., Englewood Cliffs, New Jersey. 501pp.

McCormack, D.E. K.K. Young and L.W. Kimberlin. 1982. Current Criteria for Determining Soil Loss Tolerance, pp. 95-111 in D.M. Kral (editor), Determinants of Soil Loss Tolerance. American Society of Agronomy Special Publication 45. Madison, Wisconsin.
Onchev, N.G. 1985. Universal Index for Calculating Rainfall Erosivity, pp. 424-431 in S.A. El-Swaify, W.C. Moldenhauer and A. Lo (editors), Soil Erosion and Conservation. Soil Science Society of America, Ankeny, lowa.

Renard, K.G. 1987. Present and Future Erosion Prediction Tools for Use in Pinyon-Juniper Communities, pp. 505512 in R.L Everett (editor), Proceedings -- Pinyon-Juniper Conference. US Department of Agriculture, Forest Service General Technical Report INT-215, Ogden, Utah.

Tazik, D.J., S.D. Warren, V.E. Diersing, R.B. Shaw, R.J. Brozka, C.F. Bagley and W.R. Whitworth. 1991. US Army Land Condition Trend Analysis (LCTA) Field Methods. US Army Construction Engineering Research Laboratory, Champaign, Illinois. 65pp.

United Nations Education, Scientific and Cultural Organization (UNESCO). 1973. International Classification and Mapping of Vegetation. Series 6, Ecology and Conservation. Paris, France. 93pp.

US Department of the Army. 1978. Training Land. Training Circular 25-1. Washington, DC. 166pp.

Warren, S.D., V.E. Diersing, P.J. Thompson and W.D. Goran. 1989. An Erosion-Based Land Classification System for Military Installations. Environmental Management 13:251257.

Warren, S.D. M.O. Johnson, W.D. Goran and V.E. Diersing. 1990. An Automated, Objective Procedure for Selecting Representative Field Sample Sites. Photogrammetric Engineering and Remote Sensing 56:333-335.

Westervelt, J.D. (editor). 1988. Users and Programmers Manual for the Geographical Resources Analysis Support System Version 3.0. US Army Construction Engineering Research Laboratory ADP Report N-87/22, Champaign, Illinois.

Wischmeier, W.H. 1959. A Rainfall Erosion Index for the Universal Soil Loss Equation. Soil Science Society of America Proceedings 23:246-249.

Wischmeier, W.H. 1975. Estimating the Soil Loss Equation's Cover and Management Factor for Undisturbed Areas. Sediment Yield Workshop Proceedings, Oxford, Mississippi. US Department of Agriculture, ARS-S-40.

Wischmeier, W.H. and D.D. Smith. 1978. Predicting Rainfall Erosion Losses -- A Guide to Conservation Planning. US Department of Agriculture, Agriculture Handbook 537. Government Printing Office, Washington, DC. 58pp.

Wolff, R.D. 1990. Army Land Inventory and Monitoring Procedures on Military Installations. US Army Engineering and Housing Support Center Technical Note 420-74-3, Fort Belvoir, Virginia. 


\title{
Applications of Remote Sensing in Asia and Oceania --- Environmental Change Monitoring ---
}

\author{
Edited by Shunji Murai \\ General Secretary, Asian Association on Remote Sensing
}

Features

1. 55 well illustrated case studies on practical applications of remote sensing in Asia andOceania.

2. Some $\mathbf{1 0 0}$ scientists contributed their expertise and experience in the respective fields of specialization.

3. $\mathbf{1 4 5}$ pages of vivid color illustrations, including satellite images, charts, and diagrams.

4. Printed on quality art paper in a large format of $81 / 4 "$ " 11 " to facilitate reading and interpretation (384 pages).

\section{Contents}

Editor's Preface by Shunji Murai; The Need: Land Information and Monitoring through Remote Sensing? by HRH Princess Maha Chakri Sirindhorn; Ecological Balance and Optimal Management of Natural Resources by U.R. Rao; International Cooperation for the Asia and Pacific Era by Chen Shupeng; Timely Contribution to "Mission to Planet Earth" by Adigun Ade Abiodun

1. Global Monitoring (3 papers)

2. Agricultural Development (4 papers)

3. Deforestation (5 papers)

4. Vegetation Cover (5 papers)

5. Natural Resources (4 papers)

6. Desertification (3 papers)

7. Mapping from Space (4 papers)
8. Land Use (7 papers)

9. Disaster Monitoring (4 papers)

10. Mangrove (3 papers)

11. Coastal Changes ( 3 papers)

12. Ocean Resources ( 3 papers)

13. Snow and Ice (4 papers)

14. Geology (3 papers)

Published in October 1991; US\$30.00 a copy (Surface mail postage: US\$3.00) (Special discount price: US\$25.00 a copy for quantity orders of more than 10 copies)

Available from: Geocarto International Centre, G.P.O. Box 4122, Hong Kong Tel: (852) 5464262 ; Fax: (852) 5593419

\section{Order Form}

To: Geocarto International Centre, G.P.O. Box 4122, Hong Kong

Enclosed is my check for US\$33.00. Please send me one copy of the book.

Name: (Mr/Mrs/Miss/Dr/Prof)

Address:

City: State: Code: Country: 